\title{
Evaluation of Zinnia (Zinnia elegans L.) Genotypes under West Garo Hills District, Meghalaya, India
}

\author{
Sunil Kumar* and Balisha Marwein \\ Department of Horticulture, North Eastern Hill University, Tura Campus, Tura-794 002, West \\ Garo Hills District, Meghalaya, India \\ *Corresponding author
}

\begin{tabular}{|l|}
\hline Ke y w or d s \\
$\begin{array}{l}\text { Zinnia, Evaluation, } \\
\text { Growth, Flowering, } \\
\text { Quality, Vase-life }\end{array}$ \\
\hline Article Info \\
\hline $\begin{array}{l}\text { Accepted: } \\
18 \text { April } 2018 \\
\text { Available Online: } \\
\text { 10 May } 2018\end{array}$ \\
\hline
\end{tabular}

A B S T R A C T

Evaluation of Zinnia (Zinnia elegans L.) genotypes under West Garo Hills District, Meghalaya was carried out at the experimental farm Department of Horticulture, NEHU, Chandmari, Tura Campus, during 2016-2017 to identify the suitable variety for successful cultivation and flower production under prevailing agro-climatic conditions. Eleven varieties namely, Zinnia Royal Purple, Zinnia Double Mixed, Zinnia Illuminated Deep Rose, Zinnia Dreamland Takii, $F_{1}$ Tall Zinnia Red, Zinnia Orange King, Zinnia Double Orange, $F_{1}$ Elegans Zinnia Pink, Zinnia Dahlia Flowered, Zinnia Polar Bear White and Zinnia Cherry Queen were selected for their evaluation. The experiment was laid out in Completely Randomized Design (CRD) with four replications. Uniform package of practices were followed throughout the experiment to grow a healthy crop. Highest plant height in cultivar $F_{1}$ Elegans Zinnia Pink $(136.25 \mathrm{~cm})$, number of leaves in cv. Zinnia Polar Bear White (121.00), E-W plant spread in cv. Zinnia Cherry Queen $(50.59 \mathrm{~cm})$, stem diameter in cv. Zinnia Orange King $(12.18 \mathrm{~cm})$ were noticed. However, leaf length $(11.00$ $\mathrm{cm})$ and internodal length $(10.55 \mathrm{~cm})$ in $\mathrm{cv}$. Zinnia Double Mixed, number of branches (13.50) and N-S plant spread $(43.75 \mathrm{~cm})$ in cv. Zinnia Double Orange, leaf breadth $(5.25$ $\mathrm{cm})$ and leaf area $\left(37.67 \mathrm{~cm}^{2}\right)$ in $\mathrm{cv}$. Zinnia Royal Purple were observed. Whereas, minimum days to bud initiation (36.00 days) in cv. Zinnia Dreamland Takii, maximum flower duration (57.25 days) in cv. Zinnia Double Orange was obtained. Highest ray floret length $(2.95 \mathrm{~cm})$ and width $(1.07 \mathrm{~cm})$ in $\mathrm{cv} . \mathrm{F}_{1}$ Tall Zinnia Red, number of ray floret per head (57.00), fresh weight of flower per head $(1.77 \mathrm{~g})$, dry weight of flower per head $(0.91$ g) and number of flower head per plant (7.75) in cv. Zinnia Dreamland Takii were found. While, maximum number of flowers per spray per plant (4.15) and vase life of zinnia flowers under tap water (8.14 days) was recorded with cv. Zinnia Cherry Queen followed by cv. Zinnia Dreamland Takii (6.00 days) were recorded.

\section{Introduction}

Zinnia (Zinnia elegans L.) exhibit considerable diversity with respect to growth habit, flower colours, shape, size, unique bloom structures and colour patterns. It can easily be grown in beds, pots, window boxes and rock gardens. Zinnia blooms have wide variety of bi-coloured ray florets and a highly double-flowered capitula type, which increase its ornamental value compared to single and semi-double zinnia type capitula. These 
flowers are relatively easy to grow, begin flowering as young plants, continue to produce flowers throughout the growing season and are excellent cut-flowers. The proper selection of zinnia cultivars is indeed a secret of success and expected to increase yield by enhancing the number and size of flowers. Varieties that respond well in local climatic condition protect themselves from depredation of insect, pest and diseases and as result vigorous growth occurs to face the seasonal hazards.

Plants got tensile strength to sustain the high velocity winds and more number of healthy and beautiful flowers with greater size is produced to enhance aesthetic value. The need has been felt with an increased demand of cut flowers particularly in summer when a few summer annuals bloom. Temperature is a major determinant of the rate of plant development and under climate change.

Warmer temperatures that shorten development stages of determinate crops will most probably reduce the yield of a given variety. Also, different cultivars of Zinnia under diverse climatic conditions behave in a different way. Zinnia flower responds well in high temperature.

West Garo Hills District, Meghalaya is agroclimatically very much suited for cultivation of zinnia during spring and summer season due to prevailing high temperature. However, performance of cultivars is also influenced by agro-climatic factors. Hence, there is a need to evaluate some of the promising cultivars of zinnia with extended vase life in these areas so that suitable cultivars could be recommended for commercial cultivation. Therefore, the present research has been designed to evaluate the performance of various zinnia cultivars and to identify suitable cultivars that perform better in local climatic conditions of West Garo Hills District, Meghalaya.

\section{Materials and Methods}

\section{Study area and statistical method}

The present study entitled "Evaluation of Zinnia (Zinnia elegans L.) genotypes under West Garo Hills District, Meghalaya" was carried out at the experimental farm of Horticulture Department, NEHU, Chandmari, Tura Campus, during 2016 and 2017. The district is situated approximately between the latitudes $90^{\circ} 30^{\prime}$ and $89^{\circ} 40^{\prime} \mathrm{E}$, and the longitudes of $26^{\circ}$ and $25^{\circ} 20^{\prime} \mathrm{N}$. It has an average elevation of 349 metres (1145 feet). The prevalent climate of the region is subtropical, experiences a relatively high temperature in summer and cool winters. Average rainfall is $4203.8 \mathrm{~mm}$ which occurs mostly during the monsoon season.

The experiment was laid out in completely randomized design (CRD) with eleven treatments and four replications. Eleven cultivars namely, Zinnia Royal Purple, Zinnia Double Mixed, Zinnia Illuminated Deep Rose, Zinnia Dreamland Takii, $\mathrm{F}_{1}$ Tall Zinnia Red, Zinnia Orange King, Zinnia Double Orange, $\mathrm{F}_{1}$ Elegans Zinnia Pink, Zinnia Dahlia Flowered, Zinnia Polar Bear White and Zinnia Cherry Queen were selected for their evaluation. The seeds were procured from private companies and sown in the pro trays during March 2016. The well-established seedlings of zinnia varieties were transplanted during April 2016 into the pots of $30 \mathrm{~cm} \times 30$ $\mathrm{cm}$ size. The pots were filled with garden soil and well rotten farm yard manure (FYM) in the ratio of $1: 1$. Uniform package of practices were followed throughout the experiment to grow the healthy crop. Routine intercultural operations were done as per the requirement. Observations were made on various vegetative growth and flowering characters as well as vase-life under tap water. The data collected were analysed using statistical methods as suggested by Gomez and Gomez (2010). 


\section{Results and Discussion}

\section{Performance of Zinnia cultivars for growth characters}

Significant differences were observed in vegetative and flowering characters among the zinnia cultivars. There were significant differences among the varieties in respect to vegetative parameters (Table 1). Cultivar elegance pink showed highest plant height $(136.25 \mathrm{~cm})$ followed by cherry queen $(120.14$ $\mathrm{cm})$ but was on par with cultivar double orange $(133.50 \mathrm{~cm})$, dreamland takii $(129.25$ $\mathrm{cm})$, while, it was minimum in cultivar polar bear white $(66.25 \mathrm{~cm})$. The significant variation with respect to plant height among the chrysanthemum varieties were also noticed by Dewan et al., (2016), Ona et al., (2015), Srilatha et al., (2015) and in gerbera by Sangma et al., (2017) and Singh et al., (2015). Pasha et al., (2015) also observed the significant response among the zinnia cultivars for morphological traits under the agro-climatic conditions of Faisalabad. The number of branches was significantly higher in cultivar (13.50) followed by cultivar illuminated deep rose (11.75) which was on par with dreamland takii (11.25) and royal purple (11.00). However, cultivar dahlia flower showed lowest number of branches (7.00). Such variations in vegetative growth parameters have also been reported by Chobe et al., (2010) in gerbera. Differences in vegetative characters of different cultivars of zinnia may be due to varied growth rates and their genetic potential resulted in variation in phenotypic expression. The number of leaves was significantly higher in cultivar polar bear white (121.00) and was on par with cultivar dreamland takii (117.00) and the least number of leaves (62.07) was obtained from cultivar dahlia flowered. It has been reported by Lucidos et al., (2013) that vegetative characteristics of plants are greatly influenced by genetic environmental factors.
Significant increased length of leaf had been shown by cultivar double mixed $(11.00 \mathrm{~cm})$ followed by cultivar dreamland takii (8.92 $\mathrm{cm})$, whereas, breadth of leaf was significantly higher in cultivar royal purple $(5.25 \mathrm{~cm})$ and was on par with tall red $(4.80 \mathrm{~cm})$, dreamland takii (4.62) and cherry queen $(4.60 \mathrm{~cm})$. Maximum E-W plant spread was associated with cultivar cherry queen $(50.59 \mathrm{~cm})$ followed by double orange $(41.50 \mathrm{~cm})$ and was on par with dreamland takii, while, N-S plant spread was observed significantly higher in cultivar double orange $(43.75 \mathrm{~cm})$ which was on par with cultivar cherry queen (43.64 $\mathrm{cm})$, orange king $(43.00 \mathrm{~cm})$, tall red $(42.75$ $\mathrm{cm})$, dahlia flowered $(42.00 \mathrm{~cm})$ and dreamland takii $(41.50 \mathrm{~cm})$. Cultivar royal purple $(30.00 \mathrm{~cm})$ recorded to be the lowest in $\mathrm{N}-\mathrm{S}$ plant spread.

The difference in plant spread per plant is a varietal trait as it is governed by the genetical makeup. Similar variations in plant spread per plant among varieties were also observed in China aster by Munikrishnappa et al., (2013). Differences in plant spread might also be due to bigger sized leaves produced by cultivars. Leaf production of any crop decides the spread of plant; leaves are the prime important functional units for photosynthesis, which greatly influence the growth and flower yield.

These results are corroborate with the findings of Singh et al., (2017), Sangma et al., (2017), Dewan et al., (2016), Deka and Talukdar (2015). Variation in plant spread may also be due to additive gene effects (Vidalie et al., 1985). Significant increased leaf area was noticed in cultivar royal purple $\left(37.67 \mathrm{~cm}^{2}\right)$ and was on par with cultivar tall red (36.11 $\left.\mathrm{cm}^{2}\right)$, double mixed $\left(35.41 \mathrm{~cm}^{2}\right)$ and dreamland takii $\left(34.95 \mathrm{~cm}^{2}\right)$. However, lowest leaf area was found in cultivar illuminated deep rose $\left(22.64 \mathrm{~cm}^{2}\right)$. Similar results were observed by Vikas et al., (2015) in dahlia genotypes. Cultivar dreamland takii showed 
significantly decreased internodal length (7.42 $\mathrm{cm})$ which was on par with cultivar orange queen $(7.57 \mathrm{~cm})$, dahlia flowered $(8.25 \mathrm{~cm})$ and illuminated deep rose $(8.82 \mathrm{~cm})$, while, the cultivar double mixed showed increased intermodal length $(10.55 \mathrm{~cm})$. Stem diameter was found to be maximum in cultivar orange king $(12.18 \mathrm{~mm})$ followed by dreamland takii (10.03 $\mathrm{mm})$ but was on par with polar bear white $(11.86 \mathrm{~mm})$, tall red $(11.83 \mathrm{~mm})$ and cherry queen $(11.47 \mathrm{~mm})$.Different cultivars showed variable responses for vegetative characteristics and cultivars under study were given same soil and climatic conditions but variations occurred. This might be due to their genetic composition which interacts differently to the soil and climatic condition of the prevailing area. Safiullah and Ahmed (2001) also confirmed about variation in vegetative and floral characteristics in gladiolus cultivars. The differences in various vegetative growth parameters might be attributed to inherent genetic characters of the varieties evaluated. The similar observations have been reported by Deepa and Patil (2016) in marigold, Praneetha (2006) and Kumar and Yadav (2005) in gerbera.

\section{Performance of Zinnia cultivars for flowering characters}

Quality and flowering parameters for Zinnia cultivars varied significantly (Table 2). One can observe variations among floral characteristics for different cultivars. Cultivar dreamland takii took minimum days (36.00 days) for bud initiation which was on par with illuminated deep rose and double orange, while, it was maximum in cultivar Zinnia Cherry Queen (46.50 days) for bud initiation. These results were in accordance with the findings of Vetrivel and Jawaharlal (2014) in chrysanthemum. Deka and Talukdar (2015) also noticed least number of days to first bud initiation in gerbera. The differences in bud initiation might be due to genetical makeup of the genotypes (Suma and Patil, 2006). Kumar et al., (2013) also observed these variations among floral characteristics of gladiolus cultivars.

Minimum days to first colour shown and days to full bloom after first colour shown was also associated with cultivar dreamland takii (2.50and 9.25 days) followed by cultivar polar bear white (5.00 and 11.25 days) which was on par with royal purple (5.50 and 11.50 days), dahlia flowered (5.75 and 12.00 days) and tall red (6.25 and 12.50 days) while, it was maximum in cultivar double mixed $(8.25$ and 15.75 days). Enhanced flower longevity after full bloom was obtained with cultivar illuminated deep rose (28.75 days) followed by dreamland takii (19.39 days) and orange king (17.75 days), whereas, cultivar elegance pink recorded reduced flower longevity after full bloom (12.25 days). Earliness in gerbera flowering (Barua and Bordoloi, 2015) in dahlia (Gupta et al., 2015) and highest values in terms of flower longevity in dahlia (Vikas et al., 2015) had also been noticed. Number of days taken for flower bud appearance and first flowering is an important character that signifies earliness or late flowering and determines the flower availability. The variation in time to flowering might be due to the genotype or the influence of genotype and environment. The variation in time to flowering of different chrysanthemum genotypes was also reported by Rao and Pratap (2006), Behera et al., (2002) and Singh et al., (2008) under different locations. Cultivar Double Orange showed highest flower duration (57.25 days) which was on par with cultivar polar bear white (56.75 days), orange king (54.75 days) and dreamland takii (52.75 days). While, lowest flowering duration was found in cultivar elegance pink (45.25 days). The variation in flowering duration among the varieties was attributed to genotype of the plant, environmental influence and other management factors. 
Table.1 Performance of zinnia cultivars for growth characters under West Garo Hills District, Meghalaya

\begin{tabular}{|c|c|c|c|c|c|c|c|c|c|c|}
\hline Cultivars & $\begin{array}{l}\text { Plant } \\
\text { Height } \\
\text { (cm) }\end{array}$ & $\begin{array}{l}\text { Number } \\
\text { of } \\
\text { Branches }\end{array}$ & $\begin{array}{l}\text { Number } \\
\text { of } \\
\text { leaves }\end{array}$ & $\begin{array}{l}\text { Leaf } \\
\text { length } \\
\text { (cm) }\end{array}$ & $\begin{array}{l}\text { Leaf } \\
\text { breadth } \\
(\mathrm{cm})\end{array}$ & $\begin{array}{c}\text { Plant } \\
\text { Spread } \\
(\mathrm{cm}) \\
\text { E-W }\end{array}$ & $\begin{array}{c}\text { Plant } \\
\text { Spread } \\
\text { (cm) } \\
\text { N-S }\end{array}$ & $\begin{array}{l}\text { Leaf } \\
\text { Area } \\
\left(\mathrm{cm}^{2}\right)\end{array}$ & $\begin{array}{c}\text { Inter } \\
\text { nodal } \\
\text { Length } \\
\text { (cm) }\end{array}$ & $\begin{array}{l}\text { Stem } \\
\text { Diamete } \\
\mathbf{r}(\mathbf{c m})\end{array}$ \\
\hline $\begin{array}{l}\mathbf{T}_{1}-\text { Zinnia } \\
\text { Royal Purple }\end{array}$ & 83.25 & 11.00 & 101.50 & 10.25 & 5.25 & 37.25 & 30.00 & 37.67 & 10.07 & 9.49 \\
\hline $\begin{array}{l}\text { T2 }- \text { Zinnia } \\
\text { Double Mixed }\end{array}$ & 111.25 & 7.75 & 84.75 & 11.00 & 3.60 & 37.25 & 37.50 & 35.41 & 10.55 & 10.74 \\
\hline $\begin{array}{l}\text { T3 }- \text { Zinnia } \\
\text { Illuminated Deep } \\
\text { Rose }\end{array}$ & 92.00 & 11.75 & 77.00 & 8.45 & 3.75 & 37.25 & 41.50 & 22.64 & 8.82 & 10.00 \\
\hline $\begin{array}{l}\text { T}_{4}-\text { Zinnia } \\
\text { Dreamland Takii }\end{array}$ & 129.25 & 11.25 & 117.00 & 8.92 & 4.62 & 35.75 & 41.50 & 34.95 & 7.40 & 10.03 \\
\hline $\begin{array}{l}\mathbf{T}_{5}-\mathbf{F}_{1} \text { Tall } \\
\text { Zinnia Red }\end{array}$ & 119.00 & 8.25 & 72.50 & 10.85 & 4.80 & 33.00 & 42.75 & 36.11 & 9.32 & 11.83 \\
\hline $\begin{array}{l}\mathrm{T}_{6}-\text { Zinnia } \\
\text { Orange King }\end{array}$ & 116.50 & 8.75 & 72.00 & 10.55 & 4.52 & 34.25 & 43.00 & 30.88 & 7.57 & 12.18 \\
\hline $\begin{array}{l}\mathbf{T}_{7}-\text { Zinnia } \\
\text { Double Orange }\end{array}$ & 133.50 & 13.50 & 102.50 & 9.35 & 3.92 & 41.50 & 43.75 & 27.46 & 9.17 & 11.35 \\
\hline $\begin{array}{l}\mathrm{T}_{8}-\mathrm{F}_{1} \text { Elegans } \\
\text { Zinnia Pink }\end{array}$ & 136.25 & 8.50 & 99.75 & 9.50 & 4.12 & 33.25 & 36.75 & 27.74 & 9.50 & 11.46 \\
\hline $\begin{array}{l}\text { T9-Zinnia } \\
\text { Dahlia Flowered }\end{array}$ & 126.25 & 7.00 & 62.07 & 9.52 & 4.87 & 32.50 & 42.00 & 30.68 & 8.25 & 11.05 \\
\hline $\begin{array}{l}\text { T10 - Zinnia } \\
\text { Polar Bear } \\
\text { White }\end{array}$ & 66.25 & 10.75 & 121.00 & 10.12 & 4.02 & 49.75 & 41.00 & 29.91 & 8.80 & 11.86 \\
\hline $\begin{array}{l}\mathbf{T}_{11}-\text { Zinnia } \\
\text { Cherry Queen }\end{array}$ & 120.14 & 7.39 & 78.25 & 9.74 & 4.60 & 50.59 & 43.64 & 32.18 & 10.19 & 11.47 \\
\hline CD (0.05) & 13.61 & 1.43 & 11.79 & 1.94 & 0.83 & 7.09 & 8.86 & 5.54 & 1.56 & 1.97 \\
\hline CV & 8.40 & 10.32 & 9.09 & 13.66 & 13.18 & 12.83 & 10.23 & 12.47 & 11.94 & 12.40 \\
\hline
\end{tabular}


Table.2 Performance of zinnia cultivars for flowering characters under West Garo Hills District, Meghalaya

\begin{tabular}{|c|c|c|c|c|c|c|c|c|c|}
\hline Cultivars & $\begin{array}{l}\text { Days to } \\
\text { bud } \\
\text { initiation } \\
\text { (days) }\end{array}$ & $\begin{array}{l}\text { Days to } \\
\text { first colour } \\
\text { shown after } \\
\text { initiation } \\
\text { (days) }\end{array}$ & $\begin{array}{l}\text { Days to full } \\
\text { bloom after } \\
\text { first colour } \\
\text { shown } \\
\text { (days) }\end{array}$ & $\begin{array}{l}\text { Flower } \\
\text { longevity } \\
\text { after full } \\
\text { bloom } \\
\text { (days) }\end{array}$ & $\begin{array}{l}\text { Flowerin } \\
\text { g } \\
\text { duration } \\
\text { (days) }\end{array}$ & $\begin{array}{l}\text { Stalk } \\
\text { length } \\
(\mathrm{cm})\end{array}$ & $\begin{array}{l}\text { Flower } \\
\text { diamete } \\
\text { r (cm) }\end{array}$ & $\begin{array}{l}\text { Flower head } \\
\text { height (cm) }\end{array}$ & $\begin{array}{l}\text { Vase life } \\
\text { (days) }\end{array}$ \\
\hline $\begin{array}{l}\text { T}_{1}-\text { Zinnia Royal } \\
\text { Purple }\end{array}$ & 43.00 & 5.50 & 11.50 & 15.00 & 49.75 & 13.80 & 5.15 & 2.06 & 6.00 \\
\hline $\begin{array}{l}T_{2}-\text { Zinnia Double } \\
\text { Mixed }\end{array}$ & 43.25 & 8.25 & 15.75 & 17.00 & 46.50 & 12.55 & 5.25 & 2.05 & 6.00 \\
\hline $\begin{array}{l}T_{3}-\text { Zinnia } \\
\text { Illuminated Deep } \\
\text { Rose } \\
\end{array}$ & 36.75 & 7.00 & 13.50 & 28.75 & 56.25 & 13.15 & 5.25 & 2.12 & 7.00 \\
\hline $\begin{array}{l}\mathrm{T}_{4}-\text { Zinnia } \\
\text { Dreamland Takii }\end{array}$ & 36.00 & 2.50 & 9.25 & 19.39 & 52.75 & 16.07 & 6.60 & 2.10 & 7.00 \\
\hline $\begin{array}{l}T_{5}-F_{1} \text { Tall Zinnia } \\
\text { Red }\end{array}$ & 41.50 & 6.25 & 12.50 & 13.75 & 51.25 & 13.97 & 5.80 & 2.02 & 6.00 \\
\hline $\begin{array}{l}\mathrm{T}_{6}-\text { Zinnia Orange } \\
\text { King }\end{array}$ & 40.25 & 7.50 & 14.25 & 17.75 & 54.75 & 10.65 & 7.20 & 2.15 & 6.00 \\
\hline $\begin{array}{l}\mathrm{T}_{7}-\text { Zinnia Double } \\
\text { Orange }\end{array}$ & 37.25 & 6.5 & 14.75 & 14.00 & 57.25 & 13.25 & 4.95 & 1.92 & 6.00 \\
\hline $\begin{array}{l}T_{8}-F_{1} \text { Elegans } \\
\text { Zinnia Pink }\end{array}$ & 42.25 & 6.75 & 13.50 & 12.25 & 45.25 & 12.52 & 4.75 & 2.05 & 6.00 \\
\hline $\begin{array}{l}\text { T9-Zinnia Dahlia } \\
\text { Flowered }\end{array}$ & 40.25 & 5.75 & 12.00 & 17.00 & 49.50 & 9.90 & 4.75 & 1.97 & 6.00 \\
\hline $\begin{array}{l}\text { T}_{10}-\text { Zinnia Polar } \\
\text { Bear White }\end{array}$ & 41.25 & 5.00 & 11.25 & 13.50 & 56.75 & 16.70 & 4.65 & 1.92 & 6.00 \\
\hline $\begin{array}{l}\text { T }_{11}-\text { Zinnia Cherry } \\
\text { Queen }\end{array}$ & 46.50 & 8.00 & 15.00 & 15.25 & 51.38 & 12.19 & 6.94 & 2.02 & 8.14 \\
\hline $\mathrm{CD}(0.05)$ & 2.85 & 1.24 & 1.80 & 5.27 & 10.96 & 2.30 & 0.39 & 0.17 & 0.12 \\
\hline CV & 4.85 & 13.73 & 9.55 & 10.47 & 14.61 & 12.66 & 4.87 & 6.09 & 1.32 \\
\hline
\end{tabular}


Table.3 Performance of zinnia cultivars for quality characters under West Garo Hills District, Meghalaya

\begin{tabular}{|c|c|c|c|c|c|c|c|c|}
\hline Cultivars & $\begin{array}{l}\text { Ray } \\
\text { floret } \\
\text { length } \\
(\mathrm{cm})\end{array}$ & $\begin{array}{l}\text { Ray } \\
\text { floret } \\
\text { width } \\
(\mathrm{cm})\end{array}$ & $\begin{array}{l}\text { Number } \\
\text { of ray } \\
\text { florets/he } \\
\text { ad }\end{array}$ & $\begin{array}{l}\text { Fresh } \\
\text { weight of } \\
\text { flower/head } \\
\text { (g) }\end{array}$ & $\begin{array}{l}\text { Dry weight } \\
\text { of } \\
\text { flower/head } \\
\text { (g) }\end{array}$ & $\begin{array}{l}\text { Number } \\
\text { of flower } \\
\text { head per } \\
\text { plant }\end{array}$ & $\begin{array}{l}\text { Number } \\
\text { of flowers } \\
\text { per spray } \\
\text { per plant }\end{array}$ & $\begin{array}{l}\text { Number of } \\
\text { sprays per } \\
\text { plant }\end{array}$ \\
\hline $\begin{array}{l}T_{1}-\text { Zinnia Royal } \\
\text { Purple }\end{array}$ & 2.25 & 0.97 & 42.25 & 1.50 & 0.76 & 6.50 & 1.75 & 5.75 \\
\hline $\begin{array}{l}T_{2}-\text { Zinnia Double } \\
\text { Mixed }\end{array}$ & 2.22 & 0.95 & 30.50 & 1.38 & 0.75 & 5.50 & 1.50 & 6.50 \\
\hline $\begin{array}{l}T_{3}-\text { Zinnia } \\
\text { Illuminated Deep } \\
\text { Rose }\end{array}$ & 2.35 & 1.05 & 25.25 & 1.26 & 0.67 & 5.00 & 1.25 & 5.75 \\
\hline $\begin{array}{l}\mathrm{T}_{4}-\text { Zinnia } \\
\text { Dreamland Takii }\end{array}$ & 2.75 & 1.07 & 57.00 & 1.77 & 0.91 & 7.75 & 3.25 & 7.75 \\
\hline $\begin{array}{l}T_{5}-F_{1} \text { Tall Zinnia } \\
\text { Red }\end{array}$ & 2.95 & 1.07 & 43.50 & 1.59 & 0.80 & 4.75 & 1.25 & 5.25 \\
\hline $\begin{array}{l}\text { T}_{6}-\text { Zinnia Orange } \\
\text { King }\end{array}$ & 2.37 & 1.12 & 43.25 & 1.59 & 0.79 & 4.00 & 1.50 & 5.75 \\
\hline $\begin{array}{l}T_{7}-\text { Zinnia Double } \\
\text { Orange } \\
\end{array}$ & 2.25 & 1.00 & 47.50 & 1.60 & 0.82 & 4.25 & 1.25 & 5.25 \\
\hline $\begin{array}{l}\mathrm{T}_{8}-\mathrm{F}_{1} \text { Elegans } \\
\text { Zinnia Pink }\end{array}$ & 2.20 & 0.97 & 37.75 & 1.50 & 0.78 & 3.75 & 1.25 & 5.00 \\
\hline $\begin{array}{l}\text { T9-Zinnia Dahlia } \\
\text { Flowered }\end{array}$ & 1.87 & 0.95 & 32.00 & 1.49 & 0.70 & 3.25 & 1.25 & 5.00 \\
\hline $\begin{array}{l}\text { T10 }- \text { Zinnia Polar } \\
\text { Bear White }\end{array}$ & 2.12 & 1.05 & 21.25 & 1.16 & 0.61 & 3.50 & 1.00 & 5.00 \\
\hline $\begin{array}{l}\text { T }_{11}-\text { Zinnia Cherry } \\
\text { Queen }\end{array}$ & 2.69 & 1.06 & 34.37 & 1.41 & 0.70 & 2.37 & 4.15 & 3.72 \\
\hline $\mathrm{CD}(0.05)$ & 0.42 & 0.21 & 7.17 & 0.28 & 0.10 & 0.65 & 0.28 & 0.91 \\
\hline $\mathbf{C V}$ & 12.35 & 14.28 & 12.99 & 12.97 & 9.02 & 9.84 & 12.88 & 11.44 \\
\hline
\end{tabular}


Similar results for variation in flowering duration among the genotypes have also been reported in chrysanthemum under different environmental conditions (Swaroop et al., 2008, Singh et al., 2008; Rao and Pratap, 2006) and Momin et al., (2015) in gladiolus. Significant increased stalk length was observed in cultivar Polar Bear White (16.70 $\mathrm{cm})$ followed by tall red $(13.97 \mathrm{~cm})$ but was on par with dreamland takii $(16.07 \mathrm{~cm})$. However, cultivar dahlia flowered showed the decreased stalk length $(9.90 \mathrm{~cm})$. Sarmah et al., (2014) and Barooah et al., (2009) also reported more stalk length in gerbera.

Maximum flower diameter was shown by cultivar orange king $(7.20 \mathrm{~cm})$ followed by cherry queen $(6.94 \mathrm{~cm})$ and was on par with dreamland takii $(6.60 \mathrm{~cm})$, while, cultivar polar bear white recorded minimum flower diameter $(4.65 \mathrm{~cm})$. The increased flower diameter might be due to more number of ray florets recorded in the same genotypes. Variations in flower diameter were also noticed by Negi et al., (2015) in chrysanthemum and Kumar et al., (2013) in gladiolus. Flower head height was significantly higher in cultivar illuminated deep rose $(2.12 \mathrm{~cm})$ and was on par with orange king $(2.15 \mathrm{~cm})$ and dreamland takii $(2.10 \mathrm{~cm})$.

The reduction in flower head height was found in cultivar polar bear white $(1.92 \mathrm{~cm})$. However, prolonged vase-life of zinnia cut flowers was observed in cultivar Cherry Queen (8.14 days) followed by cultivar illuminated deep rose (7.00 days) which was on par with cultivar dreamland takii (7.00 days), whereas, the minimum vase-life was recorded in cultivar royal purple (6.00 days). Variation in vase-life may be attributed to differential accumulation of carbohydrates from varied leaf production, sensitivity of cultivars to ethylene and genetical framework of the plant. Kumar and Yadav (2005), Kumar et al., (2013) and Mishra (2015) had also reported similar results of vase-life in cut gladiolus.

\section{Performance of Zinnia cultivars for quality characters}

Different cultivars responded or interact with prevailing soil and climatic conditions depending upon their genetic compositions. Increased ray floret length was observed in cultivar tall red $(2.95 \mathrm{~cm})$ which was on par with dreamland takii $(2.77 \mathrm{~cm})$ and cherry queen $(2.69 \mathrm{~cm})$, whereas, minimum number of ray floret length was recorded from cultivar dahlia flowered $(1.87 \mathrm{~cm})$.However, cultivar orange king showed the maximum ray floret width $(1.12 \mathrm{~cm})$ and was on par with dreamland takii $(1.07 \mathrm{~cm})$ and tall red $(1.07 \mathrm{~cm})$ but reduced ray floret width was associated with double mixed $(0.95 \mathrm{~cm})$ and dahlia flowered $(0.95 \mathrm{~cm})$. These results corroborate with the findings of Vasudevan and Rao (2010) in gerbera (Table 3).

Cultivar dreamland takii had the maximum number of ray florets per head (57.00) followed by double orange $(47.50)$ and was on par with tall red (43.50), orange king (43.25) and royal purple (42.25). Minimum number of ray florets per head was recorded in cultivar polar bear white (21.25).Maximum fresh and dry weight of flower per head was also noted with cultivar dreamland takii (1.77 $\mathrm{g}$ and $0.91 \mathrm{~g}$ ) which was on par with double orange $(1.60 \mathrm{~g}$ and $0.82 \mathrm{~g})$, tall red $(1.59 \mathrm{~g}$ and $0.80 \mathrm{~g}$ ) and orange king $(1.59 \mathrm{~g}$ and $0.79 \mathrm{~g}$ ), while, minimum fresh and dry weight of flower per head was observed in cultivar polar bear white $(1.16 \mathrm{~g}$ and $0.61 \mathrm{~g})$. The differences in fresh weight of flower head may be due to inherent characters of the individual cultivars. These findings are also in accordance with the results of Kumar (2014) who reported wide differences in quality parameters among chrysanthemum cultivars. 
Highest number of flower head per plant showed by cultivar dreamland takii (7.75) followed by royal purple (6.50) and double mixed (5.50). Whereas, lowest number of flower head per plant was noted from cultivar cherry queen (2.37). More number of flower head per plant was also reported by Ona et al., (2015) and Srilatha et al., (2015) in chrysanthemum. However, cultivar cherry queen exhibited maximum number of flowers per spray per plant (4.15) followed by dreamland takii (3.25) and royal purple (1.75). Minimum number of flower per spray per plant was associated with cultivar polar bear white (1.00). Highest number of spray per plant was recorded with cultivar dreamland takii (7.75) followed by double mixed (6.50), tall red (5.25) and double orange (5.25), while, minimum number of spray per plant was observed in cultivar cherry queen (3.72).Highest number of sprays per plant was also noticed by (Kumar, 2014) in chrysanthemum, Vasudevan and Rao (2010) in gerbera and Gulia et al., (2017) in marigold.

The present investigation for evaluation of different genotypes of zinnia, cultivars dreamland takii, double orange, royal purple, orange king, double mixed, tall red and cherry queen showed better performance for vegetative, flowering and quality characters under climatic conditions of Tura, West Garo Hills district, Meghalaya and recommended for its commercial cultivation. Also, considerable morphological variations were observed among vegetative and floral characters that could be considered as useful selection criteria for further improvement in chrysanthemum.

\section{References}

Barooah, L., Choudhury and Talukdar, M. 2009. Evaluation of different gerbera (Gerbera jamesonii Bolus ex Hooker
F.) cultivars under agro-climatic conditions of Jorhat, Assam. J.Orn. Hort. 12: 106-10.

Barua, U. and Bordoloi, R. 2012. Performance of gerbera cultivars under low cost polyhouse. Prog. Hort., 44(1): 37-39.

Behera, T.K., Sirohi, P.S. and Anand, P. 2002. Assessment of chrysanthemum germplasm for commercial cultivation under Delhi condition. J. Orn. Hort., 5(2): 11-14.

Chobe, R.R., Pachankar, P.B. and Warade, S.D. 2010.Studies on genetic variability and heritability in gerbera. Asian $J$. Hort., 10: 356-358.

Deepa, V. P and Patil, V. S. 2016. Evaluation of marigold hybrids (Tagetes spp.) for their growth and yield potential under Dharwad condition. J. Farm Sci., 29(2): 235-237.

Deka, K. and Talukdar, M.C. 2015. Evaluation of gerbera cultivars for growth and flower character under Assam conditions. J. Agri. Vet. Sci., 8(4): 28-30.

Dewan N., Kumar S., Sharma S. and Chakraborty S. 2016.Evaluation of chrysanthemum (Chrysanthemum morifolium Ramat) genotypes under West Garo Hills District, Meghalaya. HortFlora Res. Spectrum, 5(3): 189194.

Gomez, K.A., and Gomez, A.A. 2010. Statistical Procedure for Agricultural Research, Wiley India (P) Limited, New Delhi.

Gulia, R. Beniwal, B. S., Sheoran, S. and Sandooja, J.K. 2017. Evaluation of marigold genotypes for growth, flowering, yield and essential oil content. Res. Crops, 18(2): 299-304.

Gupta, A. K., Jaiswal, N. K. and Sarvanan, S. 2015. Varietal Evaluation of Different Hybrids of Dahlia (Dahlia variabilis L.) under Allahabad Agro-Climatic 
Conditions. International Journal of Agricultural Science and Research, 5(1): 55-58.

Kumar, R. (2014). Evaluation of chrysanthemum genotypes for flowering traits under open grown condition. HortFlora Res. Spec., 3(4): 388-389.

Kumar, R. and Yadav, D. S. 2005. Evaluation of gerbera (Gerbera jamesonii Bolus ex Hooker F.) cultivars under sub-tropical hills of Meghalaya. J. Orn. Hort. 8: 212-15.

Kumar, S., Momin, K. C., Momin, B. C. and Marak B. R. 2013. Evaluation of gladiolus (Gladiolus hybrida) cultivars for flower and corm production under Pasighat (Arunachal Pradesh) condition, Current Hort., 1(2): 16-20.

Kumar, S., Roy, R.K., Tewari, S.K. and Goel, A.K. 2012. Evaluation of performance of gerbera varieties growing in naturally ventilated polyhouse in Lucknow Botanical Garden CSIR-National. Botanical Res. Inst., Lucknow. 44 (3): 363-365.

Lucidos, J.G., Kwang, B.R., Younis. A., Kim, C.K. and Hwang, Y.J. 2013. Different day and night temperatures responses in Lilium hansonii in relation to growth and flower development. Horticulture, Environment and Biotechnology. 54: 405-411.

Mishra, P. 2015. Post-harvest flowering behaviour of some gladiolus varieties grown under Faizalabad Climatic Condition. HortFlora. Res. Spectrum. 4(1): 64-66.

Momin, B.C., Kumar, S., Momin, K.Ch. and Dewan, N. 2015. Evaluation of gladiolus (Gladiolus grandiflorus L.) genotypes under West Garo Hills District, Meghalaya. HortFlora Res. Spectrum, 4(3): 224-229.

Munikrishnappa, P. M. Patil, A. A., Patil, V. S., Patil, B. N. Channappagaoudar B. B. and Alloli, T. B. 2013.Studies on the growth and yield parameters of different genotypes of China aster (Callistephus chinensis Nees.). Karnataka J. Agric. Sci., 26 (1): 107-110

Negi, R., Jarial, K., Kumar, S. and Dhiman, S. 2015. Evaluation of Different Cultivars of Chrysanthemum Suitable for Low Hill Conditions of Himachal Pradesh. J. Hill Agric., 6(2): 144-146.

Ona, A.F., Roni, M.Z.K., Ahmad, H. and Jamal Uddin, A.F.M. 2015. Study on growth and flower yield of five snowball varieties. Bangladesh Res. Pub. J., 11(3): 182-186.

Pasha, M.F., Ahmad, H.M., Qasim, M. and Javed, I. 2015. Performance evaluation of zinnia cultivars for morphological traits under the Agro-climatic conditions of Faisalabad. European J. Biotech. Biosci., 3 (1): 35-38.

Praneetha, S. 2006. Performance of gerbera (Gerbera jamesonii Bolus ex Hooker F.) genotypes at Shervaroy hills of Tamil Nadu. J. Orn. Hort., 9: 55-57.

Rao, A.M. and Pratap, M. 2006.Evaluation of chrysanthemum (Dendranthema grandiflora Tzvelev). J. Orn. Hort., 9(2): 221-223.

Safiulla, A. and Ahmed, M.J. 2001. Evaluation of exotic cultivars of gladiolus at Rawalakot conditions. B.Sc. (Agri.) thesis, Department of Horticulture, College of Agriculture, Rawalakot Azad Kashmir, Pakistan.

Sangma, S.M. Kumar, S. Collis, J.P. and Momin, B. C. 2017. Performance of gerbera (Gerbera jamesonii Bolus ex Hooker F) cultivars for growth, flowering and yield characters under naturally ventilated polyhouse. J. Orn. Hort., 20 (3\&4): 108-112

Sarmah, D., Kolukunde, S. and Mandal, T. 2014. Evaluation of gerbera varieties for growth and flowering under polyhouse 
in the plains of West Bengal, Int. J. Sci. Res., 3(12): 135-136.

Singh, A., Mahawer, L. N. and Bairwa, H. L. 2017. Evaluation of Perennial Chrysanthemum Cultivars under SubHumid Southern Plains and Aravali Hills of Rajasthan. Indian J. Hort., 74(3): 423

Singh, A., Patle, N.K. and Maiti, C.S. 2015. Performance of exotic gerbera cultivars grown under protected conditions in Nagaland. Int. J. Farm Sci., 5(3): 98101.

Singh, K.P, Prasad, V.K. and Raju, D.V.S. 2008.Evaluation of chrysanthemum (Dandrenthema grandiflora) germplasm in winter season under Delhi condition. J. Orn. Hort., 11(1): 58-61.

Singh, S., Kumar, R. and Poonam. 2008. Evaluation of chrysanthemum (Dendranthema grandiflora Tzvelev) open pollinated seedling for vegetative and floral characters. J. Orn. Hort., 11(4): 271-274.

Srilatha, V., Kumar, S.K. and Kiran, D.Y. 2015.Evaluation of chrysanthemum varieties in southern zone of Andhra Pradesh. Agri. Sci. Digest, 35(2): 155157.

Suma, V. and Patil, V.S. 2006. Flower
Quality Parameters in Daisy (Aster amellus L.) Genotypes. Karnataka J. Agric. Sci., 19(3): 653-656.

Swaroop, K., Prasad, K.V. and Raju, D.V.S. 2008. Evaluation of chrysanthemum (Dendranthema grandiflora Tzvelev) germplasm in winter season under Delhi conditions. J. Orn. Hort., 11(1): 58-61.

Vasudevan, V. and Rao, V. K. 2010. Evaluation of gerbera (Gerbera jamesonii Bolus ex Hooker F.) genotypes under mid hill conditions of Garhwal Himalaya. J. Orn. Hort., 13(3): 195-199.

Vetrivel, T. and Jawaharlal, M. 2014.Evaluation of chrysanthemum varieties for yield and quality under subtropical hills. Trends Bio. Sci., 7(14): 1812-1815.

Vidalie, H., Laffaire, M., Revere, L.M. and Charperitier, S. 1985. First results on the performance of gerbera cultivated on rockwool. Revue. Horticole, 262: 1318.

Vikas, H.M., Patil, V.S. and Dorajeerao, A.V.D. 2015. Evaluation of Dahlia genotypes based on vegetative and quality characters. Pl. Arch., 15(1): 283286.

\section{How to cite this article:}

Sunil Kumar and Balisha Marwein. 2018. Evaluation of Zinnia (Zinnia elegans L.) Genotypes under West Garo Hills District, Meghalaya, India. Int.J.Curr.Microbiol.App.Sci. 7(05): 22022212. doi: https://doi.org/10.20546/ijcmas.2018.705.257 